УДК 398.8(=163.3):2-264

https://doi.org/10.55302/MF2180143g

Gerlinde Glaser

\title{
THE ENIGMA OF MYTHICAL TASKS OR PROMISES AND COSMIC IMAGES IN MACEDONIAN BALLADS
}

\begin{abstract}
The love songs or ballads hailing the accomplishments of the maiden bride follow the ritual pattern of praise directed at the Great Goddess and are set within the framework of the archaic marriage contest, i.e. the female and the male competing to prove themselves worthy of each other. contest.

Keywords: love songs, female practices, celebration of the Great Goddess, marriage

Powerful metaphors relating to the maiden in Macedonian folkloristic texts suggest a celebration of the female principle as personified by the Great Goddess in her aspect as Virgin. Thereby the rich display of cosmic symbols serves the aim of glorifying the maiden bride in the pre-marriage drama. Her characteristics and accomplishments resemble those ascribed to the Goddess Isis in an anonymous prayer:
\end{abstract}

Kein Tag, keine Stunde, kein kurzer Augenblick vergeht, da du nicht deine Gaben ausschüttest.

Auf dem Meer and auf dem Lande, überall

Schützest du die Menschenkinder

Und breitest deine Rechte über sie aus,

verscheuchst des Lebens Stürme

und entwirrst die hoffnungslos verwirrten Fäden des Schicksals,

du linderst die Unwetter des Verhängnisses

und hinderst der Sterne unheilvollen Lauf.

Dich ehren die Götter droben,

dir dienen die Geister der Unterwelt,

du lässt kreisen das Weltenrund,

du erleuchtest die Sonne,

regierst die Welt, zertrittst die Hölle.

Dir antworten die Gesteine,

zu dir kehren die Jahreszeiten,

deiner freuen sich die Götter,

dir dienen die Elemente. -

(Not a day, not an hour and not a moment pass when you do not heap your gifts upon us. At sea and on land, everywhere you protect the children of men by spreading your hands over them; you chase off the storms of life and unravel the hopelessly entangled threads of fate; you soften the tempests of disaster and you change the fatal course of the stars. You are venerated by the gods above, you are served by the demons of the underworld; you are in charge of the circling globe, you make the sun 
shine, you command the world and you crush hell. You are the mistress of the rocks, the seasons turn to you, you are the gods' joy and the elements serve you $)^{1}$

(Hunke 1955: 50).

Like Isis she appears as the nourishing principle, a lunar medium in liminal space or the seasonally awaking winter princess; she clothes the world or spins the human destiny, weaves the cosmos, commands the waters, the moon and the sun, couples with the fierce dragon-snake or the golden-antlered stag and bears the solar symbols.

The love songs and ballads hailing the accomplishments of the maiden bride basically follow the archaic pattern of a marriage contest, i.e. the female and the male competing to prove themselves worthy of each other. The Russian text evoking Love Goddess Lada to sanction the archaic ritual of the marriage competition between the bull and the maiden is an example of the sacred practice.

Oj, Tur, molo decu daloj:

On iz goro da bol'šogo

Vyzyval krasnu devicu

Snimna travke poborotisja!

Oj Dido Lado poborotisja!

(The mighty and daring aurochs from the big city challenged the beautiful maiden to a fight in the grass! Oj, Dido, Lado to compete with each other!)

(Sacharov 1849, I, III: 261).

It must, however, be observed that the texts are not only concerned with the contestants in the marital drama but also with the stimulation of the seasonal awakening brought about by the union of the female and the male principle.

In the ballad Terzii braća terzii the dressmaker brothers, undisputed masters in the ritual art of clothing or embellishing the female body, promise to sew the maiden a bridal shirt without using measurement, needles or thread under the condition that she bakes them a "kravaj" (a festive cake or bread) without using a sieve, water or fire:

Terzii, braća terzii, Aj sošijte mi bel fustan, bez aršin da go merite, bez nožici da go skroite, bez igla da go šiete, bez konec da go berete! Devojče, vraško ǵavolče, Aj da ni mesiš kravajče, bez sito da go otseeš,

${ }^{1}$ This and all other translations are mine. 
bez voda da go zamesiš,

bez ogin da go ispečeš!

Terzii, braća terzii,

jas će vi mesam kravajče,

niz klepki će go otseam,

so solzi će go zamesam,

na gradi će go ispečam!

("My dear dressmaker brothers, sew me a white dress without measurement, scissors, needles or thread!" "Devilish maiden, make us a cake without sieving the flour, kneading the dough, without water and baking it without fire! "My dear dressmaker brothers, I will make you a cake; I will sieve the flour through my eyelashes, I will knead the dough with my tears and will bake it on my bosom!")

(ZbMNP 1947: 85).

The maiden's promise to bake bread by relying on her physical endowments is a metaphor for female creativity or fecundity, which may bring forth all the earthly goods in abundance in order to nourish and sustain human, animal and vegetal life. At the same time it is a praise of the Goddess in her all-encompassing generosity. Furthermore, the mythic accomplishments of both the male and the female point to the pattern of a marriage contest, which is staged to establish the contestants' exceptionality.

Other dressmakers are confronted with the ritual task of designing a dress for a maiden on the basis of her shadow: "devojko, majstor mi od senka fustan ti kroi" (Miladinovci 1962: 435); this may hint at the female's magic radiation.

When the mythical dressmakers fling their broken needles into the sea, bridges come into being; along those, the Lazarki, maidens who are being subjected to an archaic pre-marriage ritual, move along.

The South Slavic dance of the lazar maidens (Macedo-Bulgarian), Lazarice or Kraljice (Serbian), reflects an archaic lunar fertility ritual: positioned in the shape of the moon crescent, the dancing females mime the movement of the celestial bodies, and in particular that of the moon (Kulišić 1979: 95-111). The stomping of their bare feet is to magically stimulate the soil's productive energy ("Bosonoge one dodiruju zemlju i tako na nju prinose svoju plodnost"), and their long unbraided hair is to further the growth of the vegetation (Kujundžić-Ostojić 2015). A similar Polish ritual promises plenty of wheat: "Gdzie krolewna chodzi / Tam przeniczka rodzi" (Kulišić 1979: 99) (Where the queens walk the wheat grows). In Bulgaria the Lazarki are expected to jump high when dancing so the grain may grow tall; they also go round meadows and fields, stop at rivers and lakes, where their dancing and singing shall bring well-being and prosperity (Dečeva \& Komitska 1999: 50-51; Tolstoj, Radenkovič 2001: 328-329). During the re-enactment of the magic ritual the Kraljice wear small protective mirrors in their headdresses, signifying their liminal character and therefore their vulnerability (Kujundžić-Ostojić 2015).

Šijat šijat terzii, na visoki dimani, igli im se kršea, 


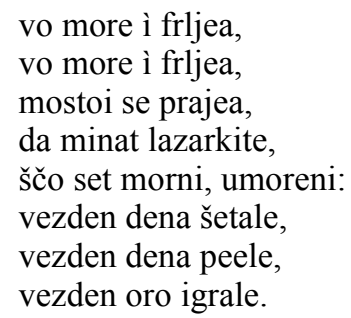

(The dressmakers are sewing seated on their high sofa; their needles break and they fling them into the sea, fling them into the sea; along the bridges that rise from the water the lazar maidens move, tired, very tired from all the walking, singing and dancing)

(Tachov 1895: 200).

Here again the dressmakers appear in a mythical dimension: the needles they crush supply the material for a bridge or pathway across the sea into the netherworld, along which the maiden moon dancers direct their steps.

The maiden (and her lover) bedded amidst the frozen three-year old layers of snow in the white stillness of nature evokes the image of the stepdaughter taken into the wintery woods to meet death among the ice and snow in the Russian tale Morozko.

Na rid imat do tri beli snega,

Eden lanski, drugijo lumlanski,

Ovoj tretij, lele, godinašni;

a nasrede malku raskopnato,

i na raskopnato postela poslana,

na postela ludo i devojka...

(On the height of the ridge there are three layers of white snow, last year's, the snow of the year before last and this year's snow; in the middle there is a hollow where a bed has been prepared, a bed for the groom and the maiden-bride... )

(Šapkarev 1891-1894: 1, 109).

...he took the homeless child into the wide field, dumped her onto a snow-drift, blessed her and quickly made for home... The poor child was left there trembling with cold and praying her prayers. There comes the Iceman hopping and jumping with pleasure and glimpses at the lovely maiden: "Maiden, maiden, I am the rednosed Iceman!" - "Welcome, Iceman; god has sent you to me, sinful soul". The Iceman wanted to crush and freeze her; but he liked her clever speech and felt pity! He flung a fur coat at her. She put it on, gathered her legs under it and sat there

(Afanasyev 2010: 112).

Both females are shown as insensitive to ice and snow; the first is the mythical winter goddess about to awaken and open the spring skies while the second is passing a trial of initiation at the hand of the Iceman. 
In the following ballad the weaver and the blacksmith are engaged in a marriage contest.

Te kažuvaet, Ilino mome,

da si tenko prela.

Jas će ti dadam, Ilino mome,

trista drama pamuk.

Ti da mi istkaeš, Ilino mome, trista lakti platno.

Što će ti ostane, Ilino mome, edna bela riza.

Te kažuvaet, kuvendži Ǵorǵi, da si majstor bilo.

Jas će ti dadam, kuvendži Ǵorǵi,

edna zlatna para.

Ti da mi napraviš, kuvendži Ǵorǵi,

eden zlaten razboj.

Što će ti ostane, kuvendži Ǵorǵi,

eden zlaten prsten.

(Maiden Ilina, you are a good spinner. I will give you, maiden Ilina, three hundred dram of cotton. You shall weave three hundred yard of cloth, maiden Ilina. There will be enough left for a white wedding shirt." "Blacksmith Georgi, you are a good craftsman. I will give you, blacksmith Georgi, a golden coin. You will forge me a golden loom. And from what is left forge me a golden ring)

(Hadžimanov 1953-1956: IV, 10).

While the maiden bride as the mythical spinner or weaver watches over human destiny and provides the world with her cloth, the groom as the mythical blacksmith knows the secret art of forging the universe.

It seems that in archaic thought the labour of producing thread from a shapeless mass of wool or flax created the same awe as the forming of a tool from stone or iron, so that spinning, like smithcraft, was imbued with magical properties. Just as in myth the creation of the world is often achieved with the help of a specifically manufactured tool or weapon, so the destiny of men is wrought through the spinning of a thread

(Motz 1984: 160-161).

The maiden ressembles of the females in magic tales who attract attention with their magic gift:

At the end of winter the cloth had been woven; it was so transparent that you could see through it. After it had been bleached in spring and Vasilisa asked the crone to sell it, she said that only the tsar could appreciate its fine quality 
(Afanasyev 2010: 127).

Ka by ja byla carica, -

Govorit ee sestrica, -

To na ves' by mir odna

Natkala ja polotna. -

("If I were the tsar's wife", said her sister, "I would weave a cloth for the whole world")

(Puškin 1987, Skazka o Tsare Saltane).

A esli b menja vzjal, ...ja b vytkala emu kaftan iz serebra, iz zolota, i sijal by on kak Žar-ptica.

(If he married me, I would weave for him a garment with silver and golden threads, which would make him shine like the Fiery Bird)

(Afanasyev 2010: 659).

As part of a task related to her marriage the maiden as a variety of the cosmic spinner or weaver creates the whole cosmos on her bright quilt.

Moma šari šaren jurgan;
kolku dzvezdi na nebeto,
tolku šarbi na jurgano;
misičina na nebeto,
misičina na jurgano;
letno sl'nce na nebeto,
letno sl'nce na jurgano!

(The maiden embellishes her bright quilt; she stitches the stars of the universe, the night moon and the summer sun on her quilt!)

(Paskalovski 1959: 83).

At another occasion, when against all ritual precautions the veil is lifted from the bride and her white face shines with the solar symbols, the wedding train is drowned in the dark sea. Now in an eerie marriage contest the maiden bride, although being mistaken for a deadly fish, fights for her lover's life under water.

Nazad, nazad, ribo pomorliva, ne mi grizaj tove beli fustan, tove mi je ot prvnoto ljubne, prvno ljubne Vida crnooka! Izgovori Vida crnooka:

Ej ti Pavlo, Pavlo, dober junak, Jaze ne sam si riba pomorliva, Jaze sam si Vida crnooka! 
(Off with you, wretched fish, don't gnaw at the white wedding dress; it belongs to my bride, to my first love, dark-eyed Vida!" Says dark-eyed Vida: "Pavel, my hero, I am not a wretched fish, I am dark-eyed Vida!")

(Kostić 1959: 156).

As far as her aptitude and determination is concerned, the maiden bride resembles the mighty sea juda (morskata Juda), who, while claiming to be Mary, mistress of the sea, forcefully attempts to sink Saint Nikola's and Ilija's mythical ferry boat floating in the Black Sea.

"Ej fala tebe, sveti Nikola!

Če jaze ne sam morskata Juda,

Ja sam si jaze Božata majka".

Sveti Nikola tichom govori:

"Božata majka kniga znaeše".

Toj í predade bre bela kniga,

A juda kniga i ne gledaše,

Tuku si gleda u zlaten korab,

Da go izjudi, da go udavi.

("For goodness sake, Saint Nikola, I am not the sea monster, the Juda, but God's mother." Nikola, aware that God's mother knows how to read and write, shows the monster a white book to establish her identity. Alas, the Juda disregards the book but concentrates on sinking the golden boat)

(SbNU 1889: II, 10, 12).

Confident in her power as a sea creature, the maiden bride challenges the young man to plunge himself into the raging waters to retrieve her golden casket.

Izvor voda izviraše,

beli peni isfrlaše,

vo penite zlaten sandak,

vo sandakot leži mome.

Mome zbori progovara:

Koj će mene da izvadi,

jas negova će si bidam!

(In the foaming spring water there floated the golden chest; in the chest there was the maiden. She promised to become the bride of the one who would free her).

(Hadžimanov 1953-1956: 584).

In the manner of the Great Goddess, the maiden bride commands the moon and the sun. When painting her room with the help of the shining moon, she pulls the groom into the premarital contest.

Mana šari šaren odar, em go šari, em go piši, 
po temnina, bez borina,

po jasnata mesečina.

(Mana is painting and brightening up her room in the darkness without a woodfire but with the moon shining on her).

(Šapkarev 1891-1894: 96).

The young man, who feverishly watches her, refuses his mother's invitation to sup and then go to rest.

Mari majko, stara majko,

pcite jale, večerale,

ogan gori f postejata,

iskri skoke $\mathrm{f}$ pernicata,

$\ldots$

(My dear old mother, I cannot sup, my bed is on fire, fiery sparks spring from my eiderdown... )

(Šapkarev 1891-1894: 96).

On the strength of her cosmic understanding, the maiden bride stops the sun setting so as to be able to finish stitching her bridal shirt.

Pogrij, pogrij, jasno sl'nce,

da izveza košuljata,

košuljata učenička.

Postojalo jasno sl'nce,

Postojalo e, i počekalo e,

izvezela e košuljata,

košuljata učenička.

...

("Shine, shine, bright sun, so I may finish the embroidery on my bridal shirt." The bright sun stopped and waited for the maiden to embroider her shirt)

(Verković 1961: 147).

When the maiden bride is ritually plunged into a death-like state, she proves invulnerable to the snake's venom and the heat of the glowing embers. Thus she may be said to have withstood hellish evil with divine power.

Majko le, mila majko le, koga mi zmija kladovte,

kak da me rosa obrosi;

koga mi ogan kladovte,

kak da me sonce ogrea!

("My dear mother, when you put the snake at my bosom, I felt like the dew refreshed me; when you put the glowing embers at my bosom, I felt like the sun shone on me!") 
(AnMl 1951: 66).

The intimate female relationship with the reptile surfaces in the ballad where the groom teaches his silver and golden hoofed horse how to respectfully meet the bride's mother clan.

Ga izleze mominata maća, da iznese zlatnata tepcia, na tepcia šarenata zmija, složi glava, konju, do zemjata, složi glava, konju, pokloni se!

("When the bride's mother appears with a spotted snake on a golden plate, my horse, bow your head lowly!")

(Molerovi 1954: 384).

At another occasion, the maiden bride's ride on the dragon-snake, the Goddess's most archaic partner, points to a mutually consented mythical marital union.

Zmej proleta niz gora zelena,

što pronese pod krilo šareno?

Ni pronese ubava nevesta, ja odnese sred gora zelena, ja ostavi pod zelen bor, senka drži ubava nevesta!

(The dragon-snake is flying across the green mountain; what does it carry under its bright wing? The reptile takes the pretty bride to a shady place in the green wood in the mountain!)

(MNP 1947: 6).

At another occasion the mythical golden-antlered stag, a divine variety of the aurochs and symbol of the arrival of spring, safely sees the maiden through the mountains. The image of the female ritually embellishing a bridal dress may be associated with a marriage contest.

Mi pominvit elen ot planina, elen ot planina so zlati rogoi, na zlati rogoi visoki divani, na visoki divan šarena odaja, $\mathrm{v}$ šarena odaja devojka ubaa, mi nosaše platno ot klobodan, go redeše so zlatni puloi, će go šijat so zlata iglica, će go dadit na carska devojka, da se storit mlada nevesta! 
(A stag is descending from the mountains, a stag with golden antlers; on its golden antlers there is a high sofa with a bright chamber; there a lovely maiden is stitching golden fowl with a golden needle on a linen cloth; she will give it to the tsar's daughter, the young bride!)

(Šapkarev 1891-1894: 154).

The moon's sister seeks to marry her brother to the cloud maiden, who she believes less apt to outshine him in the marriage competition. Alas, when the alleged cloud bride's veil is lifted, she displays the cosmic symbols.

Pa otkrile mladata nevesta,

ta ne bila moma oblačina,

liceto í s'nce ogrealo,

i na gradi jasna mesečina!

(When they uncovered the young bride's face, they found her not to be the cloud maiden but a maiden whose face shone like the sun and whose bosom displayed the bright moon)

(Šapkarev 1891-1894: 555).

The ballad centering on the solar bride relates to a variety of the marriage contest, the drama of cosmogony. In this respect the maiden bride resembles the legendary youngest sister of the magic tale, who promises to bear the tsar children with the celestial symbols on their foreheads and on their breasts.

Mene da me zeme careviot sin i da mu rodam dve deca, edna moma i edno momče, momata da e sos mesečina na čeloto i sos dzvezdi na gradi, momčeto sos sl'nce na čeloto i dzvezdi na gradi.

(If I were the wife of the tsarevich, I would bear him two children, a girl and a boy, both with the moon on their forehead and stars on their chest)

(Verković 1985: 51).

At another occasion it is the prince's marriage task to find his bride a celestial dress.

Caru, jaze sakam eden fustan da mi storiš, da imaš sl'nceto i mesečinata i zvezdite na vrh nego, i večer, koga da go nadenam, da sveti.

(Tsar, I want you to find me a garment showing the sun and the moon, and at night when I wear it, I want it to shine)

(Verković 1985: 87).

Marfa-tsarevna is delivered of three sons adorned with the sun, the moon and the stars: "po kolena nogi v zolote, po lokot' ruki v serebre, po kosicam časty melki zvezdočki" (legs cast in gold up to the knees, arms in silver up to the elbows, tiny stars on the hair... ) (Afanasyev 2010: 663). 


\section{CONCLUSION}

In the context of the premarital contest or drama, the maiden bride ritually appears as nourishing mother, blissful dancer between the worlds, seasonally awakening snow princess, spinner of the human fate, weaver of the cosmos, mistress of the elements and the cosmic symbols, mythical partner of the dragonsnake (or stag) and celestial bride.

\section{LITERATURE}

Afanasyev, A. 2010. Narodnye russkie skazki. Moskva.

Dečeva, M. and A. Komitska. 1999. Zwischen dem Sichtbaren und dem Unsichtbaren. Historische Kalenderbräuche aus Bulgarien. Kittseer Schriften zur Volkskunde. Ethnographisches Museum Schloß Kittsee.

Hadžimanov, V. 1953-1956. Makedonski narodni pesni, 1-4. Skopje.

Hunke, S. 1955. Am Anfang waren Mann und Frau. Hamm.

Iljoski, V. (red). 1947. MNP - Makedonski narodni pesni, sobrani na festivalite vo Bitola $i$ Štip. Skopje.

Ivanov, V. Vs. and V. N. Toporov. 1965. Slavjanskie jazykovye modelirujuščie semiotičeskie sistemy (Drevnij period). Moskva.

Koneski, B. 1947. ZbMNP - Zbirka makedonski narodni pesni. II izd. Skopje.

Kostić, S. 1959. Maleševski narodni pesni. Skopje.

Kulišić, Š. 1979. Stara slovenska religija u svjetlu novijih istraživanja posebno balkanoloških. Akademija nauka i umetnosti Bosne i Hercegovine. Djela, knjiga LVI. Centar za balkanol. ispitivanja, knjiga 3. Sarajevo.

Miladinovci. 1962. Zbornik, 1861-1961. Skopje.

Mitrev, D. and B. Koneski (red). 1951. AnMl - Antologija na makedonskata lirika. Jugoslovenska knjiga. Beograd.

Molerovi, D. i K. 1954. Narodopisni materijali ot Razloško. Sbornik na narodni umotvorenija i prirodopis. BAN, kn. XLVIII, Sofija.

Motz, L. 1984. "The Winter Goddess: Percht, Holda and Related Figures". Folklor, vol. 95, 151-166.

Nanevski, D. 1971. Ljubovni narodni pesni. Skopje.

Paskalovski, P. 1959. Narodni pesni od Egejska Makedonija. Skopje.

Puškin, A. S. 1987. Skazka o Tsare Saltane. Moskva.

Sacharov, I. P. 1849. Skazanija russkogo naroda. SPb.

Šapkarev, A. K. 1891-1894. Sbornik ot bălgarski narodni umotvorenija, kn. I-IV. Sofija.

SbNU - Sbornik za narodni umotvorenija, nauka i knižnina. 1889. Sofija.

Tachov, N. 1895. Sbornik ot makedonski bălgarski narodni pesni. Sofija.

Tolstoj, S. M. and L. Radenković. 2001. Slovenska mitologija. Beograd.

Verković, S. I. 1961. Makedonski narodni pesni. Skopje.

Verković, S. I. 1985. Makedonski narodni umotvorbi - Južno-makedonski narodni prikazni, IV. Skopje.

Vranska, C. 1940. "Apokrifite za Bogorodica i bălgarskata narodna pesen". Sbornik na b'lgarskata akademija na naukite, kniga XXXIV, 18. Sofija. 


\section{CITEOGRAPHY}

Kujundžić-Ostojić, S. 2015. Bunjevci, Kraljice.

http://bunjevci.com/site/bunjevacki-obicaji/kraljice/ [Accesed: 18.07.2015].

Герлинде Гласер

\section{ЕНИГМАТА НА МИТСКИТЕ ЗАДАЧИ И ВЕТУВАҢА ВО КОСМИЧКАТА СЛИКА ВО МАКЕДОНСКИТЕ БАЛАДИ}

\section{Резиме}

Љубовните песни или баладите фокусирани на невестата-девица претставуваат ритуална шема, којашто го открива славењето на Големата Мајка и се насочени кон натпреварите за брак во архаичното општество. Ова ги опфаќа митовите, каде што идните младоженци се натпреваруваат еден со друг за да проценат дали се еден за друг. 